\title{
Improvement of the diabetic foot upon testosterone administration to hypogonadal men with peripheral arterial disease. Report of three cases
}

\author{
Svetlana Kalinchenko*1, Alexandr Zemlyanoy² and Louis J Gooren ${ }^{3}$
}

\author{
Address: ${ }^{1}$ Russian Research Center for Endocrinology, 117136, 11 D, Ulianova, Moscow, Russia, ${ }^{2}$ A.V. Vishnevski Institute of Surgery, 117235,27 \\ B, Serpuchovskai, Moscow, Russia and ${ }^{3}$ Vrije Universiteit medical center, de Boelelaan 117, $1081 \mathrm{HV}$, Amsterdam, The Netherlands \\ Email: Svetlana Kalinchenko* - Kalinchenko@list.ru; Alexandr Zemlyanoy - Zemilianoi@fromru.com; \\ Louis J Gooren - louisjgooren@gmail.com \\ * Corresponding author
}

Published: 28 March 2009

Cardiovascular Diabetology 2009, 8:19 doi:10.1186/1475-2840-8-19

This article is available from: http://www.cardiab.com/content/8/1/19

(c) 2009 Kalinchenko et al; licensee BioMed Central Ltd.

This is an Open Access article distributed under the terms of the Creative Commons Attribution License (http://creativecommons.org/licenses/by/2.0), which permits unrestricted use, distribution, and reproduction in any medium, provided the original work is properly cited.
Received: 28 January 2009

Accepted: 28 March 2009

\begin{abstract}
Background: Lower extremity complications (neuropathy, ulceration, infection, and peripheral arterial disease) are common in diabetes mellitus. There is an inverse relation between plasma testosterone and insulin sensitivity, type 2 diabetes mellitus and $\mathrm{HbAlc}$ concentrations.

Methods: We report the beneficial effects of administration of testosterone to three men with a diabetic foot whose serum testosterone was subnormal.

Results: Upon normalization of serum testosterone there was an improvement of hyperglycemia, a decrease of leukocytes and of fibrinogen levels, an increase of antithrombin III activity and of tissue oxygen pressure. The wound showed granulation.

Conclusion: Beneficial effects of administration of testosterone to hypogonadal with a diabetic foot may be due to improved vascularization and to anti-inflammatory action.
\end{abstract}

\section{Background}

Lower extremity complications are common in patients with diabetes and include neuropathy, ulceration, infection, and peripheral arterial disease. Foot infections represent the single most common cause of hospitalization and lower extremity amputation in persons with diabetes. Foot ulceration as a result of diabetic peripheral sensory neuropathy, rigid osseous deformities and soft-tissue contractures, repetitive trauma from unprotected ambulation, and peripheral vascular disease can all lead to a limb- or even life-threatening infection.

Men with type 2 diabetes have a lower serum testosterone concentration compared to men without a history of dia- betes, and there is an inverse association between testosterone levels and HbA1c concentrations[1]. A recent systematic review and meta-analysis of cross-sectional studies indicated that testosterone levels were significantly lower in men with type 2 diabetes[2]. Further, in men with low plasma testosterone the risk of diabetes mellitus is increased[3]. One third to one half of men with type 2 diabetes mellitus are now recognized as testosterone deficient. Emerging evidence suggests that testosterone therapy may be able to reverse some aspects of metabolic syndrome[4].

Further, a low plasma testosterone level appeared to be associated with endothelial dysfunction in men inde- 
pendent of other risk factors, suggesting a protective effect of endogenous testosterone on the endothelium[5]. In addition, serum endogenous androgen concentrations were inversely associated with arterial stiffness in men with type 2 diabetes mellitus[6]. There is an association of type 2 diabetes with low testosterone values, and therefore, the effects of an intervention with testosterone are of considerable interest. In hypogonadal men, the few studies on the effects of testosterone treatment on glycemic control were divergent. One study replacing testosterone in hypogonadal men with type 2 diabetes found no effect on glycemic control[7], however another study analyzing 24 hypogonadal men with type 2 diabetes, of which 10 treated with insulin, found that testosterone replacement therapy improved glycemic control[8] confirming an earlier study[9].

In view of the potential relevance of normalization of plasma testosterone for glycemic control in type 2 diabetes and for vascular function, we undertook a pilot study and administered testosterone to men with a diabetic foot and who were found to have plasma testosterone below the reference range.

\section{Methods}

All patients received information that they received experimental treatment' to which they consented. This pilot study was approved by the institute's ethical review board. Written informed consent was obtained from each of the patients for publication of this Case Report and any accompanying images. A copy of the written consent is available for review by the Editor-in-Chief of this journal.

Patient \# 1. A 48-year-old man, presented with diagnosis: type 1 diabetes, dry necrosis of tissues in a projection of $\mathrm{V}$ bone of metatarsus (figure 1).

Results of laboratory investigations included hemoglobin $(13.1 \mathrm{~g} / \mathrm{dL})$, hematocrit $(46.6 \%)$, leukocytes $\left(9.7 \times 10^{9} /\right.$

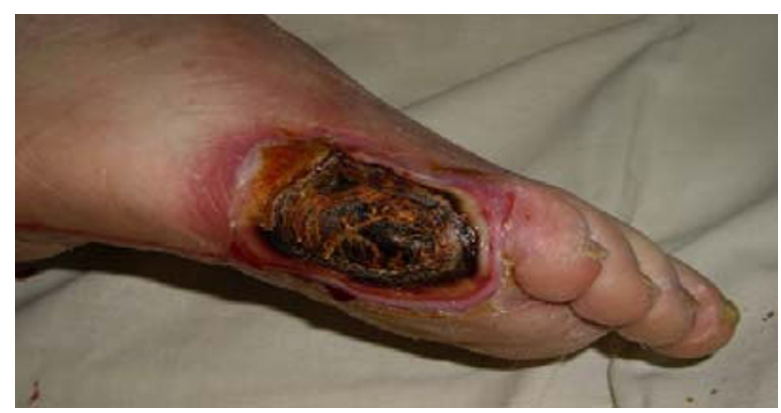

Figure I

Patient \# I before administration of testosterone.
$\mathrm{L}), \mathrm{HbA}_{1 \mathrm{c}}(7.4 \%)$, fibrinogen $(6.8 \mathrm{~g} / \mathrm{L}$ (normal range $2-4$ $\mathrm{g} / \mathrm{L})$ ), antithrombin III activity (87\% (normal range 74\%$114 \%)$ ). Other results of blood chemistry were within normal limits, except for plasma glucose $(14.0 \mathrm{mmol} / \mathrm{L})$.

Endocrinological findings: total testosterone $(7.2 \mathrm{nmol} / \mathrm{L}$ (normal range for adult men 12-35 nmol/L)). Bacteriological culture: growth of epidermal staphylococcus in the wound. Using doppler ultrasound severe stenosis of tibial arteries in the distal part of the right anticnemion was found. X-ray examination did not show signs of osteomyelitis of foot bones. Tissue oxygen tension $\left(\mathrm{TpO}_{2}\right)$ was 5 $\mathrm{mm} \mathrm{Hg}$. Daily treatment included Cefotaxim $2 \mathrm{~g}$, the heparin Fraxiparin $0.6 \mathrm{ml}$, Vessel Due F 0.5 LPE, dressing of the wound. In addition, one injection of parenteral testosterone undecanoate (TU) (1000 mg) was administered, whereupon plasma levels of total testosterone rose to $20.3 \mathrm{nmol} / \mathrm{L}$.

Results of investigations 17 days after injection of TU: decrease of leukocyte count $\left(5.6 \times 10^{9} / \mathrm{L}\right)$, plasma glucose level $(6.8 \mathrm{mmol} / \mathrm{L})$, fibrinogen level $(5.0 \mathrm{~g} / \mathrm{L})$, increased antithrombin III activity (93\%), increase of $\mathrm{TpO}_{2}(18 \mathrm{~mm}$ $\mathrm{Hg}$ ). The wound showed now granulation (figure 2). Plasma glucose level remained stable within the range of 6-8 mmol/L.

Patient \# 2., a 77-year-old man, presented to our department with diagnosis: type 2 diabetes, phlegmone of the right foot, osteomyelitis of the right calcaneus, critical ischemia of the right leg, coronary heart disease, heart failure, bilateral hydrothorax requiring continuous drainage of pleural effusion amounting to more than 2 litres per day, using permanent vacuum aspiration, renal failure (figure 3).

Results of laboratory investigations while receiving treatment with Netilmicin (0.4 g daily) and fraxiparin $(0.6 \mathrm{ml}$ daily): hemoglobin (10.4 g/dL), hematocrit (33.1\%), leu-

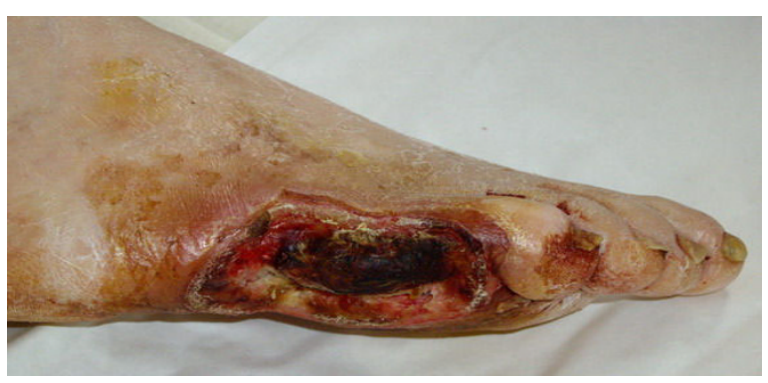

Figure 2

Patient \# I after administration of testosterone. 


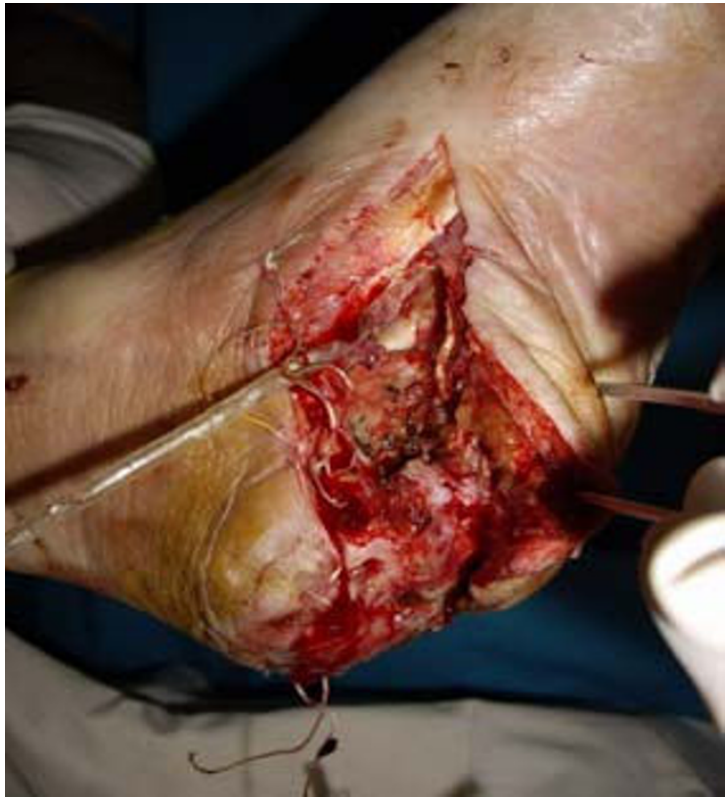

Figure 3

Patient \# 2 before administration of testosterone.

kocytes $\left(12.2 \times 10^{9} / \mathrm{L}\right)$, fibrinogen $(5.1 \mathrm{~g} / \mathrm{L}$ (normal range $2-4 \mathrm{~g} / \mathrm{L})$ ), antithrombin III activity (74\% (normal range $74 \%-114 \%)$ ), degree of aggregation - 91.9\%, rate of thrombosis - 58\%/min. Other blood chemistry tests were within normal limits, with exception of plasma glucose (10 mmol/L). A bacteriological culture revealed bacterial growth in the wound. $\mathrm{TpO}_{2}$ of the foot was $2 \mathrm{mmHg}$. Plasma testosterone levels were below normal (total testosterone $10.5 \mathrm{nmol} / \mathrm{L}$ and even more so of bioavailable testosterone: $2.58 \mathrm{nmol} / \mathrm{L}$.

Results of investigations 25 days after injection of 1000 mg testosterone undecanoate: increase of plasma testosterone to $22.5 \mathrm{nmol} / \mathrm{L}$; stabilization of general condition of the patient, relief of heart failure symptoms, hydrothorax, decrease of leukocyte level $\left(8.0 \times 10^{9} / \mathrm{L}\right)$, plasma glucose level $(6.5 \mathrm{mmol} / \mathrm{L})$, decrease of a degree of aggregation $-23.8 \%$ and rate of thrombosis $-23 \% / \mathrm{min}$., increase of antithrombin III activity (88\%), increase of $\mathrm{TpO}_{2}(50 \mathrm{mmHg})$, increase of the granulation in the wound and occurrence of border epithelization (figure 4). Glucose level remained stable within the range of 5-8 $\mathrm{mmol} / \mathrm{L}$.

Patient \# 3, a 73 year-old man, presented with the diagnosis: type 2 diabetes, diabetic foot, neuroischemic form. Gangrene of the left foot. Atherosclerotic occlusion of femoropopliteal segment. Critical ischemia of the left foot. Coronary heart disease. (figure 5).

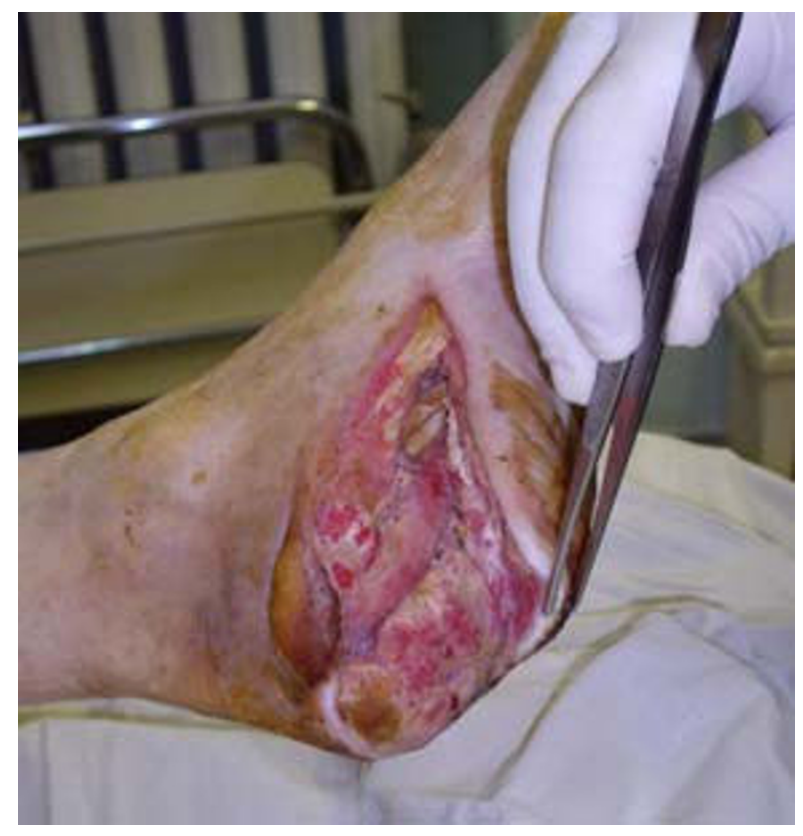

\section{Figure 4}

Patient \# 2 after administration of testosterone.

Laboratory investigations: hemoglobin $(12.6 \mathrm{~g} / \mathrm{L})$, hematocrit $(36.4 \%)$, leukocytes $\left(12,9 \times 10^{9} / \mathrm{L}\right), \mathrm{HbA}_{1 \mathrm{c}}(13.5 \%)$, fibrinogen $(6.8 \mathrm{~g} / \mathrm{L}$ (normal range $2-4 \mathrm{~g} / \mathrm{L})$ ), antithrombin III activity (63\% (normal range 74\%-114\%)).

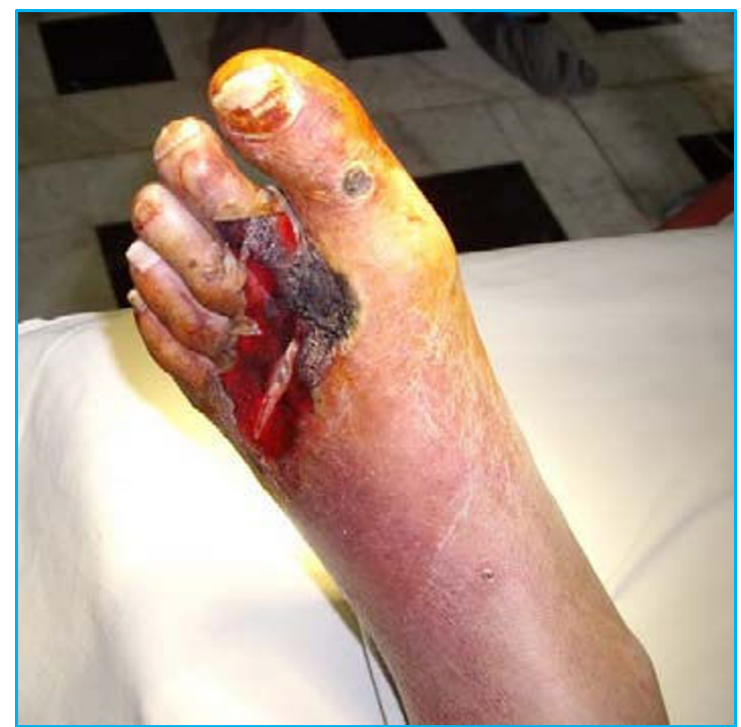

\section{Figure 5}

Patient \# 3 before administration of testosterone. 
Other blood chemistry tests were within normal limits, except for plasma glucose level (12.7 mmol/L). Plasma total testosterone was $1.9 \mathrm{nmol} / \mathrm{L}$ (normal range for adult men 12-35 nmol/L). Bacteriological culture: growth of epidermal staphylococcus in the wound. Critical stenosis of popliteal artery and arteria tibialis posterior was found by doppler ultrasound of the legs. Tissue oxygen tension $\left(\mathrm{TpO}_{2}\right)$ was $\left.28 \mathrm{~mm} \mathrm{Hg}\right)$. The patient underwent superficial femoro-peroneal shunting with autovein and marginal resection with disarticulation of toes 2-5 of the left foot. Daily treatment included Cefotaxim $2 \mathrm{~g}$, Metronidazole 600 mg, Fraxiparin $0.6 \mathrm{ml}$, Thrombo ASS $100 \mathrm{mg}$, dressing of the wound. The patient also received one injection of testosterone undecanoate $1000 \mathrm{mg}$, whereupon plasma levels of total testosterone had risen to $38 \mathrm{nmol} / \mathrm{L}$ after 14 days.

Test results after 2 months of treatment: decrease of leukocyte level $\left(8,1 \times 10^{9} / \mathrm{L}\right)$, plasma glucose level $(4.8 \mathrm{mmol} /$ $\mathrm{L})$, fibrinogen level $(5.5 \mathrm{~g} / \mathrm{L})$, increase of antithrombin III activity $(80 \%)$, increase of $\mathrm{TpO}_{2}(37 \mathrm{~mm} \mathrm{Hg})$ The wound showed granulation (figure 6). Glucose levels remained stable within the range of 4-7 $\mathrm{mmol} / \mathrm{L}$.

\section{Discussion}

There is an abundance of studies establishing that men with the metabolic syndrome, cardiovascular disease and

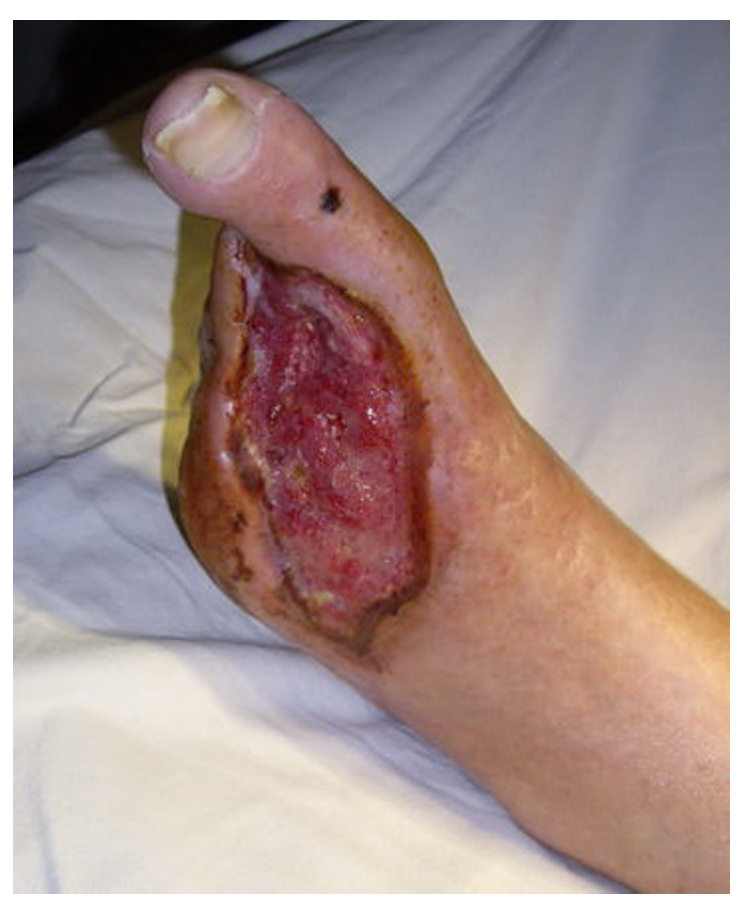

\section{Figure 6}

Patient \# 3 after administration of testosterone. type 2 diabetes have lower-than-normal circulating levels of testosterone. But, as yet, there is a paucity of studies on effects of interventions aiming to restore circulating testosterone to normal[8].

In this pilot study we administered testosterone to men with a diabetic foot who had hypogonadal testosterone levels. There were remarkable improvements.

It is as yet not possible to provide a plausible explanation for these beneficial effects. Recent studies have uncovered a multitude of effects of testosterone in male (patho)physiology which might have played a role.

1) Testosterone has a stimulatory effect on erythropoiesis occuring within weeks after testosterone administration[10]. In our patients, indeed, a rise of hemoglobin levels was found

2) There are many studies now establishing a relationship between low serum testosterone and lower extremity peripheral artery disease[11] but results of intervention studies are few. A recent study found a positive effect of administration of testosterone on vascular function[12] though most earlier studies have reported an impaired flow-mediated vasodilatation upon testosterone administration to hypogonadal men[13]. In vitro-studies or animal studies showed that testosterone can exert acute vasorelaxing effects via non-genomic mechanisms. These effects involve primarily the vascular smooth muscle, without requiring the presence of endothelium, although an endothelial contribution is apparent in some studies. To date, the mechanism behind the vasodilatory action of testosterone is still under debate and might be through either activation of $\mathrm{K}(+)$ channels or blockade of $\mathrm{Ca}(2+)$ channels in vascular muscle cells[14].

To explain the beneficial effects of administration of testosterone on the diabetic foot, a parallel may be drawn with erectile dysfunction (ED). ED may originate from vascular insufficiency and the beneficial effects of phospho-diesterase type 5 (PDE) inhibitors is well documented. The vaso-relaxation effect of $\mathrm{NO}$ on vascular smooth muscle is mediated by cyclic GMP (cGMP), which is catabolized by phosphodiesterase (PDE). PDE5 inhibitors, which are used to treat erectile dysfunction, increase the bioavailability of cGMP, which activates protein kinase $G$ thereby promoting vasodilatation resulting in penile erection. It is increasingly clear that testosterone plays a role in its own right in the vascular physiology of penile erection promoting NO production[15] and the combination of PDE5 inhibitors with testosterone has been very successful in treating erectile dysfunction[16,17]. In our patients there was an improvement of 
local oxygen pressures possibly indicating improved vascular function.

3) Apart from effects on the vascular system, testosterone may have had anabolic effects on protein synthesis[18] explaining the beneficial effects of restoring plasma testosterone to the normal range.

4) In animal experimentation androgens at physiological doses inhibit oxidative-stress-induced platelet aggregation via its receptor, which is associated with the reduction of thromboxane $\mathrm{A}(2)$ release from platelets[19]. Testosterone has also been found to have a positive effect on fibrinolysis[20]. In our patients there was a decrease of fibrinogen and an increase of antithrombin activity upon testosterone administration.

5) Inflammation is increasingly recognized as an etiological factor in cardiovascular disease [21,22] Testosterone treatment of hypogonadal men shifted the cytokine balance to a state of reduced inflammation[23]. Dihydrotestosterone positively regulated endothelial function through the control of the inflammatory response mediated by nuclear factor-kappaB in endothelial cells[24]. In our study inflammation markers were not studied but there was reduction in leukocyte counts.

6) The actions of 5alpha-dihydrotestosterone and testosterone were primarily deleterious in cutaneous wound healing in a series of studies[25]. This suggests that administration of testosterone might be unfavorable in this regard.

Our findings are observational and should invite studies with an appropriate design to explore whether normalization of testosterone levels in hypogonadal men with a diabetic foot can improve one of the most incapacitating and potentially lethal complications of diabetes mellitus.

\section{Conclusion}

Diabetes mellitus type 2 is very commonly associated with lower-tan-normal serum testosterone levels. In this study three men with a diabetic foot and subnormal serum testosterone, received testosterone treatment. The healing process of the diabetic foot took a favourable turn. This observation invites well-designed studies into the possibly favourable effects of restoring testosterone levels to normal in men suffering from a diabetic foot.

\section{Competing interests}

The authors declare that they have no competing interests.

\section{Authors' contributions}

SK and LG offered the hypothesis that administration of testosterone might be beneficial. The study was carried out by AZ and SK. All three authors have been participating in the interpretation of the data and drafting the contents of the manuscript. Each author has read and approved the final manuscript.

\section{References}

I. Svartberg J: Epidemiology: testosterone and the metabolic syndrome. Int J Impot Res 2007, I 9(2): I 24- I 28.

2. Ding EL, Song Y, Malik VS, Liu S: Sex differences of endogenous sex hormones and risk of type 2 diabetes: a systematic review and meta-analysis. Jama 2006, 295( I I): I 288- I299.

3. Zitzmann M, Faber S, Nieschlag E: Association of specific symptoms and metabolic risks with serum testosterone in older men. J Clin Endocrinol Metab 2006, 9 I ( I I ):4335-4343.

4. Spark RF: Testosterone, diabetes mellitus, and the metabolic syndrome. Curr Urol Rep 2007, 8(6):467-47I.

5. Akishita M, Hashimoto M, Ohike $Y$, Ogawa S, lijima K, Eto M, Ouchi $Y$ : Low testosterone level is an independent determinant of endothelial dysfunction in men. Hypertens Res 2007, 30(I I): 1029-1034.

6. Fukui M, Ose H, Kitagawa Y, Yamazaki M, Hasegawa G, Yoshikawa T, Nakamura N: Relationship between low serum endogenous androgen concentrations and arterial stiffness in men with type 2 diabetes mellitus. Metabolism 2007, 56(9): | I67-I I 73.

7. Basu R, Dalla Man C, Campioni M, Basu A, Nair KS, Jensen MD, Khosla S, Klee G, Toffolo G, Cobelli C, et al.: Effects of Two Years of Testosterone Replacement on Insulin Secretion, Insulin Action, Glucose Effectiveness, Hepatic Insulin Clearance and Postprandial Glucose Turnover in Elderly Men. Diabetes care 2007, 30:1972-1978.

8. Kapoor D, Goodwin E, Channer KS, Jones TH: Testosterone replacement therapy improves insulin resistance, glycaemic control, visceral adiposity and hypercholesterolaemia in hypogonadal men with type 2 diabetes. Eur J Endocrinol 2006, I 54(6):899-906.

9. Boyanov MA, Boneva Z, Christov VG: Testosterone supplementation in men with type 2 diabetes, visceral obesity and partial androgen deficiency. Aging Male 2003, 6(I): I-7.

10. Coviello AD, Kaplan B, Lakshman KM, Chen T, Singh AB, Bhasin S: Effects of graded doses of testosterone on erythropoiesis in healthy young and older men. J Clin Endocrinol Metab 2008, 93(3):9|4-9|9.

II. Tivesten A, Mellstrom D, Jutberger H, Fagerberg B, Lernfelt B, Orwoll $\mathrm{E}$, Karlsson MK, Ljunggren $\mathrm{O}$, Ohlsson $\mathrm{C}$ : Low serum testosterone and high serum estradiol associate with lower extremity peripheral arterial disease in elderly men. The MrOS Study in Sweden. J Am Coll Cardiol 2007, 50(I I): I070-I076.

12. Webb CM, Elkington AG, Kraidly MM, Keenan N, Pennell DJ, Collins $P$ : Effects of oral testosterone treatment on myocardial perfusion and vascular function in men with low plasma testosterone and coronary heart disease. Am J Cardiol 2008, I0 I (5):6 I 8-624.

13. Zitzmann $M$, Brune $M$, Nieschlag $E$ : Vascular reactivity in hypogonadal men is reduced by androgen substitution. J Clin Endocrinol Metab 2002, 87( I I):5030-5037.

14. Yildiz O, Seyrek M: Vasodilating mechanisms of testosterone. Exp Clin Endocrinol Diabetes 2007, I I 5(I): I-6.

15. Traish AM, Goldstein I, Kim NN: Testosterone and erectile function: from basic research to a new clinical paradigm for managing men with androgen insufficiency and erectile dysfunction. Eur urol 2007, 52(I):54-70.

16. Guay A, Jacobson J: The relationship between testosterone levels, the metabolic syndrome (by two criteria), and insulin resistance in a population of men with organic erectile dysfunction. J Sex Med 2007, 4(4 Pt I): I046-I055.

17. Rochira V, Balestrieri A, Madeo B, Granata AR, Carani C: Sildenafil improves sleep-related erections in hypogonadal men: evidence from a randomized, placebo-controlled, crossover study of a synergic role for both testosterone and sildenafil on penile erections. J Androl 2006, 27(2): I65-I75.

18. Bhasin S, Calof OM, Storer TW, Lee ML, Mazer NA, Jasuja R, Montori VM, Gao W, Dalton JT: Drug insight: Testosterone and selective androgen receptor modulators as anabolic therapies for 
chronic illness and aging. Nat Clin Pract Endocrinol Metab 2006, 2(3): $146-159$

19. Li S, Li X, Li J, Deng X, Li Y: Inhibition of oxidative-stressinduced platelet aggregation by androgen at physiological levels via its receptor is associated with the reduction of thromboxane A2 release from platelets. Steroids 2007, 72(13):875-880

20. Alexandersen $P$, Christiansen $C$ : The aging male: testosterone deficiency and testosterone replacement. An up-date. Atherosclerosis 2004, 173(2):157-169.

21. Bhatt DL: Anti-inflammatory agents and antioxidants as a possible "third great wave" in cardiovascular secondary prevention. Am J Cardiol 2008, I0 I (IOA):4D- I3D.

22. Hamirani YS, Pandey S, Rivera JJ, Ndumele C, Budoff MJ, Blumenthal RS, Nasir K: Markers of inflammation and coronary artery calcification: A systematic review. Atherosclerosis 2008, 20I:I-7.

23. Malkin CJ, Pugh PJ, Jones RD, Kapoor D, Channer KS, Jones TH: The effect of testosterone replacement on endogenous inflammatory cytokines and lipid profiles in hypogonadal men. J Clin Endocrinol Metab 2004, 89(7):33|3-33 I8.

24. Norata GD, Tibolla G, Seccomandi PM, Poletti A, Catapano AL. Dihydrotestosterone decreases tumor necrosis factor-alpha and lipopolysaccharide-induced inflammatory response in human endothelial cells. J Clin Endocrinol Metab 2006, II(2):546-554.

25. Gilliver SC, Ashworth J], Ashcroft GS: The hormonal regulation of cutaneous wound healing. Clin Dermatol 2007, 25(I):56-62.

Publish with Bio Med Central and every scientist can read your work free of charge

"BioMed Central will be the most significant development for disseminating the results of biomedical research in our lifetime. "

Sir Paul Nurse, Cancer Research UK

Your research papers will be:

- available free of charge to the entire biomedical community

- peer reviewed and published immediately upon acceptance

- cited in PubMed and archived on PubMed Central

- yours - you keep the copyright 